\title{
Russia's Refusal of GMO Use in the Food Industry: Problems and Prospects under the Conditions of Economic Sanctions
}

\section{Elena Vorontsova}

Faculty of Law, Southwest State University, 50 Let Oktyabrya Street 94, 305040

Kursk, the Russian Federation; proskyrinae@mail.ru

\section{Andrei Vorontsov}

Faculty of Law, Southwest State University, 50 Let Oktyabrya Street 94, 305040

Kursk, the Russian Federation; vorontsov.a.l@mail.ru

Doi:10.5901/mjss.2015.v6n6s5p345

\section{Abstract}

The article represents the authors' attempt to analyze the situation connected with the recent statement of the Russian Federation on refusal from the use of genetically modified products in the food industry. Taking into account the different opinions on this issue, the work studies the causes of transgenic technologies spread in world agriculture and the factors contributing to it. Our study also evaluates the related possible risks for Russia. The authors conclude that even a complete rejection in connection with the use of genetically modified products in food production does not guarantee the security of Russia's food market. The study focuses on some factors which, according to the authors, are creating strategic opportunities for Russia's refusal to use GMOs. Their position might be of possible interest here in relation to economic sanctions imposed against Russia, according to which, it is sanctions that have largely created the economic, political and legal conditions for adopting the decision not to use GMOs in food products. Welcoming this decision, the authors make predictions regarding its potential prospects. The paper also shows the role and importance of GMOs prohibition in achieving a number of socioeconomic goals of the Russian state.

Keywords: genetic modification, GMO, transgenic technologies, economic sanctions, food security, agricultural production, food products

\section{Introduction}

In September 2015, the government of Russia took a decision to stop the production and use of GMO products. The bill was submitted to the State Duma and there is no doubt that this law will be adopted. Earlier on, President of Russia commented on it and its position in relation to GMOs was quite clear.

Being opponents of genetically modified products, the authors of this article have repeatedly advocated its ban on the territory of the Russian Federation proving the need, and most importantly - the possibility of abandoning the use of transgenic technologies in food production. In this regard, we note with satisfaction that what we so persistently demanded, what we were talking about a few years ago has finally ended (Vorontsova, 2010). Our country becomes a territory free of GMO use in agriculture, and, we hope, it is entering on the path of environmentally clean agricultural production.

Russia took the side of those who considered genetically modified organisms as a potential threat to the health of humanity and a factor of environmental degradation. Does this mean that Russia thereby has got rid of the global risk associated with ill-conceived use of biotechnology and other possible consequences of the biotechnology revolution, which in his time F. Fukuyama warned the world about (2004) (we should mention here that he associated the biotechnology revolution not only with genetic engineering)?

It seems that there is no simple answer to this question. One thing is clear - abandoning the use of GMOs, Russia is trying to strengthen its biological and, respectively, food security. Russia could be able to evaluate the value of this for ensuring the interests of national security in general with the introduction of sanctions against the country.

In our opinion, sanctions primarily have affected the reappraisal of the current situation in the sphere of genetically modified products turnover by the Russian government and have been the accelerator of those organizational and managerial processes that led to Russia's refusal to use the products of genetic engineering in food production. 
What are the immediate effects of this development for the Russian food industry is now hard to say.

Nevertheless, it is quite probable to determine medium and long-term prospects of this step. That is what our paper will be concerned with.

\section{Objectives, Methodology and Research Design}

The aim of the present study was to analyze the possible issues and prospects of the Russian state associated with its refusal to use genetically modified foods in the face of economic sanctions.

While conducting this study, the authors were guided by the general principles of scientific character, objectivity, authenticity of the stated opinions.

All research work was built in several stages.

In the first stage, the authors considered it necessary to identify the common technological challenges of work in the field of genetic modification, which required them to turn to the history of recombinant DNA creation, and they also raised the issue about scientists' awareness of the potential dangers of genetically modified organisms in the early stages of working with them.

In the second stage of the study there were considered the main arguments of the supporters and opponents of transgenic technologies use, the most objective reasons for their wide spread and the most probable causes of the Russian Federation refusal from their use in the process of food production.

This stage focuses on the presence of an objective threat of falling genetically modified products in the Russian food market. It should be said that the ban on production and use of GMO in Russia is not regarded by the authors as an absolute panacea.

The third stage of the study is the assessment of possible perspectives associated with Russia's refusal from the use of transgenic technologies. Special attention is given to sanctions, which had crucial importance for Russia in the process of making that decision.

The third stage is the most important in the structure of our research as it gives the answer to the main question about possible perspectives of agricultural industry development in Russia (and not only) in terms of its refusal from the use of technologies of genetic modification and the presence of economic sanctions.

The basic methods of scientific study are analysis method, the method of rationale and reasoning, the method of forecasting.

The given article is a theoretical research conducted in September-October 2015. The study used the works of such authors as Barinaga M. (2000), Berg P. (1974), Fukuyama F. (2004), Jackson D.A., Berg P. \& Symons R.H. (1972), Ushachev I.G. (2009), Vir. Singh Vandana Shiva, Vinod K. Bhatt (2014). In addition, the authors used the results of own their own studies carried out previously, as well as international and Russian legislation

\section{Discussion of the Research Outcomes}

\subsection{The spread of transgenic technologies and the potential risks for Russia}

The question about the possible risks of using the technologies of genetic modification arose almost immediately with the emergence of these technologies. Paul Berg is a scientist at Stanford University is considered to be the father of genetic engineering. In 1972 he announced about the creation of the first recombinant DNA (Jackson, Berg \& Symons, 1972). In 1974 along with other leading molecular biologists, he appealed to the world scientific community through the journal "Science" to reject the experiments with recombinant DNA (i.e., artificial DNA molecules that are grouped from the already existed ones) prior to the holding of an international conference on this issue. "There is serious concern that some of these recombinant DNA molecules could prove biologically hazardous" (1974) - such was the opinion of P. Bert, and others.

There was held an international conference in 1975 in Asilomar (California, USA). That conference was widely proclaimed as "a milestone in social responsibility and self-governance of scientists" (Barinaga, 2000). Moreover, scientists concluded that the experiments in genetic engineering are no more dangerous than similar work in other branches of biotechnology. However, as elsewhere, the experiments with recombinant DNA require strict control over observance of security measures.

Indeed, integrating recipient cells of xenogeneic donor gene into the DNA is associated with certain difficulties. The main problem is connected with providing accurate targeted insertion of a gene and its normal functioning. This problem exists all the time and its solution in many cases is largely random in nature. Thus, hypothetically the real risk associated 
with the expression of a xenogeneic gene in the recipient cell always exists. All this gives reason to believe that the appearance of genotypes that are dangerous to health and life while using transgenic technologies is theoretically possible.

According to the authors of the article, even a theoretical possibility of harm to human health is sufficient to prevent industrial production of genetically modified products. However, soon after the conference in Asilomar transgenic technologies began to develop rapidly. They found commercial applications. And if their use, for example, for the production of medicines can be explained by an urgent need (as in the case of preparing insulin), or the lack of possibility to synthesize the medicine in a different way, the widespread use of technologies of genetic modification in agriculture, according to many views, are due exclusively to commercial interests of several producers of GMOs monopolizing the market.

"Only five chemical companies have won. They amassed capital in the war, then - in the production of chemicals for agriculture, and now it is genetic engineering," says well-known Indian environmental activist V. Shiva (2014). We are not going neither to deny nor agree with this statement. We should only note here that the production of GMOs really brings much more profit. In addition, the use of genetically modified seeds which, as you know, when re-seeding will not germinate, makes farmers dependent upon the manufacturers of genetically modified seeds, and this, in turn, can harm the interests of food security of any country. It is possible that the decision of the Russian Federation on refusal from the use of GMOs was based exactly upon such considerations.

However, the use of transgenic technologies in the modern world only increases. And to explain this process only by the desire of some corporations to earn means to unreasonably simplify the problem. Everything is much more complicated.

Thus, the proponents of transgenic technology use in food production have a well substantiated view on this issue. It is especially difficult to argue with the thesis that the cultivation of genetically modified crops and the purchase of cheap genetically modified products in a number of countries is simply due to the acute food shortage in these countries. Moreover, the climatic features of certain countries, the level of their economic development, let alone political instability, will not allow them to fully provide the population with food, even if genetically modified products are provided in a country itself. This, in turn, will stimulate production in other countries. For example, the largest producer of genetically modified products - the United States is focused not only on its domestic market. "This fact allows us to reasonably assume that around the world the production and distribution of genetically modified products in the near future will increase" (Vorontsova, 2010). It seems that we can agree with this conclusion now made by one of the authors several years ago.

For Russia the situation described above means that even a complete ban on the use of GMOs in the food industry does not guarantee the absolute safety of its food market.

Indeed, the flow of genetically modified raw materials and products that was previously going into the Russian Federation from the countries of Western Europe and America was involuntarily closed due to imposed economic sanctions against Russia (in that regard sanctions really benefited our country). A ban on the production of genetically modified products in our country has only strengthened the protection of the domestic market of goods. However, this does not exclude the "indirect" supplies of genetically modified products to us from third countries, i.e. the countries that did not support sanctions and with those countries Russia has trade relations. Moreover, the raw materials for food products of these countries (for example, in South and South-East Asia) both consumed in the domestic market and exported abroad (including the Russian Federation) are very often genetically modified samples from the USA and Canada. We are referring to feed for livestock, aquaculture, planting material for rice and soybean plantations, etc.).

In our opinion, concerning the countries of South and South-East Asia mentioned above, there is every reason to assume that in the near future (due to the fact of loosing the Russian market by the U.S.-Canadian manufacturers) the flow of genetically modified products from the US and Canada will only increase to the countries of that region, and through them in other parts of the world. Suffice it to recall the recent Agreement on the TRANS-Pacific partnership, which provides U.S. and Canadian companies with significant trade advantage.

Thus, the danger of appearing genetically modified products on the Russian food market still exists even after the ban on the use of GMOs. So does the need to protect Russian citizens from poor-quality products.

\subsection{Russia's refusal of GMOs: the possible consequences}

If one does not take into account Russia's obligations related to its presence in the WTO (World Trade Organization) from the point of view of the strategic conditions, our country has all opportunities for eliminating the use of GMOs in the food industry without significant harm to its food security.

The analysis of the following factors allows us to come to this conclusion: 
- firstly, unlike many countries Russia is not suffering from overpopulation. The analysis of the demographic situation shows that the real population growth is small. Moreover, some regions (Eastern Siberia, Russian Far East) are even underpopulated. Thus, the number of Russians does not exceed the capacity of the country's food production taking into account land areas suitable for farming. Russia concentrates $9 \%$ of the world food arable land (about 40 million ha of arable land), $52 \%$ of black soil, $20 \%$ of fresh water, $9 \%$ of production of mineral fertilizers (Ushachev I.G., 2009).

- secondly, acreage was decreased in the 90's and the beginning of 2000s in Russia. In our work, we have already talked about the fact that unrestricted development of new areas to be cultivated can lead to serious environmental consequences. Nevertheless, now Russia has no such a need. It is enough to return land previously used for food production into agriculture to solve the food problem of our country

- Active use of land which was formerly the agricultural land is stimulated by import substitution resulting from economic sanctions. Generally, with regard to sanctions, as applied to the problem of our study, we are inclined to consider them rather positive than negative.

- In our opinion, sanctions have largely created a real opportunity to reject the use of GMOs in the food industry of Russia. And here are the reasons:

- firstly, genetically modified foods, and genetically modified tools for the production of food came to our country mainly from abroad. With the introduction of sanctions, these deliveries stopped. In Russia, there existed a ban on the production (cultivation) of genetically modified products. Hence the industrial use of transgenic technologies was not developed;

- secondly, the implementation of import substitution in the current economic and investment situation, causes the Russian state to rely on its agro-producers which by virtue of previously mentioned reasons focus exclusively on the traditional technologies of agricultural production.

Thus, economic sanctions against Russia, (in our opinion, nonlegal in their nature as they violate the rights of citizens and entrepreneurs on both sides of the border), along with the obvious negative impact created economic, political and legal conditions in Russia for the adoption of important decisions that meet the interests of its national development. Moreover, some solutions implemented now in Russia despite their obvious need for our country simply could not be adopted and realized in terms of "pre-sanction" period. The decision to ban the use of GMOs in food industry is one of them.

Our readers will probably agree with us that in terms of the increasing list of sanctions against Russia, our country appears to have more and more moral and legal grounds in order to more calmly react to possible reproaches of Western partners regarding the fact that our refusal of import, for example, GM soy or corn violates WTO rules on freedom of movement of goods and services. Russia's position on this issue is eloquently expressed by President Vladimir Putin at a meeting with Federation Council members. According to Natural Society, he said the following: "We must build our work so that it should not contradict our obligations within the WTO. But even with this in mind we have legitimate methods and instruments to protect our own market and, above all, our citizens (2015)."

As for the ban on the use of genetically modified ingredients in any form in the food industry, Russia's refusal from transgenic technologies allows to achieve several goals at once:

- the first goal is the health of the nation. The Constitution of the Russian Federation in Article 41 proclaims the right of everyone to health. Even if later one finds out that today's concerns about the danger of GM products are only hypothetical in nature, the presence of very possibility of harm to the health is already more than enough to protect Russians from their impact. This is the role of the welfare state, which the Russian Federation proclaims itself to be. As the object of state protection, health has the quality of irreversibility in case of loss. Therefore, government action in this area should be aimed at preventing the slightest threat to public health. It is these threats that F. Fukuyama warned us about speaking about the possible consequences of biotechnology use (2004). It is those threats that the provisions of main international instruments are being focused on. Some international instruments regulate biosafety issues, such as the Convention on Biological Diversity of 5 June 1992 (1992), Council of Europe Convention for the Protection of Human Rights and Dignity of the Human Being with regard to the Application of Biology and Medicine: Convention on Human Rights and Biomedicine of 19 November 1996 (1996), The UNESCO Universal Declaration on Bioethics and Human rights of 19 October 2005 (2005).

This, in our opinion, is the true meaning of the concept of "biosecurity".

- the second goal, which can be achieved in Russia with the refusal of transgenic technologies is the rise of the national economy. The logic is obvious: supporting the Russian agro-producer in view of needs for import substitution, the government thereby objectively supports the production of ecologically clean products, as 
Russian farmers do not use GMOs.

Apart from the fact that in the absence of competitors from Europe and America Russian producers have the opportunity to become full owners of domestic agricultural market, they also have a real opportunity to significantly increase the production of "green" products. Demand for those products in developed countries is increasing from year to year. With the available land resources, Russia has all the chances to become the world's largest producer of organic products in the future.

In the context of refusal from genetically modified products there can be resolved a number of social challenges. We are talking about the development of agricultural areas, increase of population employment in general and especially in rural areas, and, consequently, improving the quality of life, which is especially important. This process may be due to a greater extensity of "natural (traditional)" agriculture in comparison with the production of products based on GMOs. For the latter type of production, as you know, it is enough to have smaller amount of agricultural land and less workers.

Thus, besides enhancing the country's food security, Russia's refusal of transgenic technologies use in agriculture might mean a number of other positive consequences for the country in the field of economic and social development.

\section{Conclusion}

The present study allowed us to draw a number of conclusions that, most likely, will not be agreed upon by all.

This situation is caused by the polarity of views on the question under discussion both among scholars and among representatives of state bodies, business structures and the representatives of public organizations (primarily environmental-protective ones).

In addition, a clearly expressed political nature of our studied topic also does not assist to certainty of existing views. And this is not surprising, because such a radical reorientation of food policy of such country as Russia cannot but cause a noticeable resonance in the world and therefore the relevant political and economic consequences as it affects the interests of a significant number of the world's agricultural corporations.

Our first conclusion is that Russia's refusal to import genetically modified raw materials for agriculture and the food industry reduces the dependence of Russian farmers on supplies from abroad and thereby strengthens food security of Russia.

The second conclusion is that a ban on production of GM products (including the cultivation of GM crops), without any doubt, works in the interests of health protection of Russian citizens, because it greatly protects the Russians from their eventual (albeit not fully proven) harmful effects. It does not make this prohibition a panacea, however, but significantly reduces the possible risks.

The third conclusion relates to the resource capabilities of the Russian Federation concerning import substitution. In our view, Russia has almost all the prerequisites in order to fully provide itself with their own food according to all major groups of food products.

The presence of territorial, soil, water, and human resources enables our country to endure sanctions regime in agriculture not without serious consequences. The Russian climate is not ideal for agriculture. That is why it can make some adjustments to this process. Although nobody is insured from crop failures, the vast territory of the Russian Federation, taking into account different climatic zones, virtually eliminates the occurrence of the total widespread crop failure.

In this case, the role of proper organization of storage and processing of agricultural products should not be neglected. Moreover, in the near future the development of processing technologies with increased efficiency is able to turn Russia into one of the largest and most successful producers of organic food.

In the meantime, it is European agricultural producers who suffer from losing the Russian market in the first turn. It should be said that American manufacturers of GM raw materials might also have such difficulties.

Thus, the refusal of Russia from the production and use of genetically modified foods will possibly be the starting point of a process that will change not only agriculture but the entire economy of our country.

\section{References}

Barinaga, M. (2000). Asilomar revisited: lessons for today? Science 287, 1584-1585.

Berg, P. (1974). Potential hazards of recombinant DNA molecules, Science 185, 303.

Council of Europe Convention for the Protection of Human Rights and Dignity of the Human Being with regard to the Application of Biology and Medicine: Convention on Human Rights and Biomedicine of 19 November 1996. Spravochno-pravovaya sistema 'Garant'. 
Fukuyama, F. (2004). Nashe postchelovecheskoe budushchee: posledstviya biotekhnologicheskoi revolyutsii [Our Posthuman Future: Consequences of Biotechnology Revolution]. Moskva: Izdatel'stvo OOO 'AST', OAO 'LJUKS'.

Jackson, D.A., Berg, P. \& Symons, R.H. (1972). Biochemical method for inserting new genetic information into DNA of simian virus 40: circular SV40 DNA molecules containing lambda phage genes and lactose operon of Escherichia coli, Proceedings of the National Academy of Sciences, USA, 69, 2904-2908.

Rossiiskaya Federatsiya reshila polnost'yu zapretit' ispol'zovat' geneticheski modifitsirovannye produkty $v$ proizvodstve edy [The Russian Federation has decided to completely ban the use of genetically modified products in food production]. [Online] Available at: http://earth -chronicles.ru / news/ (September 28, 2015).

The Convention on Biological Diversity of 5 June 1992. (1996). Sobranie zakonodatel'stva Rossiiskoi Federatsii. [Legislation Bulletin of the Russian Federation]. No.19, Article 2254

The UNESCO Universal Declaration on Bioethics and Human Rights of 19 October 2005. Spravochno-pravovaya sistema 'Garant' [Legal-reference system "Garant"].

Ushachev, I.G. (2009). Obespechenie prodovolstvennoy bezopasnosti Rossii: problemyi i puti resheniya [Ensuring Food Security of Russia: Problems and Solutions]. Agrarnoe i zemelnoe pravo. No.1, 9.

Vir, Singh Vandana Shiva, Vinod K. Bhatt. (2014). AgroEcology - Principles and Operationalisation of Sustainable Mountain Agriculture.

Vorontsova, E.V. (2010). Problema yuridicheskogo zapreta na ispol'zovanie transgennykh tekhnologiiy v Rossii: da i net s tochki zreniya konstitutsionnogo prava na bezopasnost' zdorov'ya [The problem of legal prohibition of the usage of transgenic technologies in Russia: "yes" and "no" from the position of the constitutional right to health security]. Izvestiya Kurskogo gosudarstvennogo tekhnicheskogo universiteta. No.3 (32), 113-120. 